\title{
Study of evaporation and seepage losses from farm pond in saline area
}

\section{Y.R. MAHALLE AND G.W. ADHAU}

Received : 19.04.2014; Revised : 26.08.2014; Accepted : 09.09.2014

See end of the Paper for authors' affiliation

Correspondence to :

\section{Y.R. MAHALLE}

S.P. College of Food Science and Technology, KharawateDahiwali, RATNAGIRI (M.S.) INDIA

Email : gajananadhau@yahoo.com
-ABSTRACT : Farm ponds have traditionally been used as an economical and efficient way to retain water for livestock, watering and irrigation. Water harvesting through farm pond and utilization of conserved water for cultivated field is very crucial for promoting sustainable agriculture in Saline Area. The traditional concept of locating dug out structures at strategic locations was revived and promoted as farm ponds. To overcome the drought prone situation in drought affected districts of Vidarbha, constructions of number of dug out type ponds (water storage structures) for harvesting of excess rain water on farmers field is the best option available and is being implemented since last three years. Research Concluded evaporation and seepage loss component from unlined dug out type farm pond was found to be 58.82 and $12.60 \mathrm{~cm}$, respectively during three months of water storage period (October to December). The evaporation component in Lined Black polyethylene was found to be in the range of 19.51 to 24.60 per cent of storage period. The one protective irrigation using harvested in runoff water in dug out farm ponds resulted in increases in the dry land productivity of Cotton and Gram crops to 47 to 55 per cent and 43 to 58 per cent, respectively.

GEY WORDS : Farm pond, Water harvesting, Saline area, Evaporation, Polythelene

- HOW TO CITE THIS PAPER : Mahalle, Y.R. and Adhau, G.W. (2014). Study of evaporation and seepage losses from farm pond in saline area. Internat. J. Agric. Engg., 7(2) : 402-409. 